Pfizer, Regeneron, Roche/Genentech, Sanofi, Selecta, Takeda, UCB, and Viela Bio, Grant/research support from: AbbVie, Aclaris, Amgen, AstraZeneca, Bristol-Myers Squibb, Eli Lilly, Gilead, Idorsia, Novartis, Oscotec, Pfizer, Regeneron, Roche/Genentech, Sanofi, Selecta, Takeda, UCB, and Viela Bio, Jerzy Swierkot Speakers bureau: AbbVie, Accord, BMS, Janssen, MSD, Pfizer, Roche, Sandoz, and UCB, Consultant of: AbbVie, Accord, BMS, Janssen, MSD, Pfizer, Roche, Sandoz, and UCB, Grant/research support from: AbbVie, Accord, BMS, Janssen, MSD, Pfizer, Roche, Sandoz, and UCB, Alan Friedman Shareholder of: May own stock or options in AbbVie, Employee of: AbbVie, Nasser Khan Shareholder of: May own stocks or options in AbbVie, Employee of: AbbVie, Yihan Li Shareholder of: May own stocks or options in AbbVie, Employee of: AbbVie, Xianwei Bu Shareholder of: May own stocks or options in AbbVie, Employee of: AbbVie, Justin Klaff Shareholder of: May own stock or options in AbbVie, Employee of: AbbVie, Vibeke Strand Consultant of: AbbVie, Amgen, Arena, AstraZeneca, Bayer, Bristol-Myers Squibb, Boehringer Ingelheim, Celltrion, Eli Lilly, Genentech/ Roche, Gilead, GSK, Ichnos, Inmedix, Janssen, Kiniksa, MSD, Myriad Genetics, Novartis, Pfizer, Regeneron, Sandoz, Sanofi, Setpoint, and UCB DOI: 10.1136/annrheumdis-2021-eular.530

\section{POS0656 RELATIONSHIP BETWEEN CHANGES IN LIPID LEVELS AND IMPROVEMENT IN DISEASE ACTIVITY OUTCOMES IN PATIENTS WITH RHEUMATOID ARTHRITIS RECEIVING UPADACITINIB TREATMENT: POOLED ANALYSIS OF DATA FROM TWO PHASE 3 STUDIES}

C. Charles-Schoeman ${ }^{1}$, J. T. Giles ${ }^{2}$, N. Lane ${ }^{3}$, E. Choy ${ }^{4}$, H. Camp ${ }^{5}$, Y. Song ${ }^{5}$, S. Anyanwu ${ }^{5}$, I. Mclnnes ${ }^{6}{ }^{1}$ University of California, Rheumatology, Los Angeles, United States of America; ${ }^{2}$ Columbia University, Rheumatology, New York, United States of America; ${ }^{3}$ University of California, Davis, Sacramento, United States of America; ${ }^{4}$ Cardiff University, School of Medicine, Cardiff, United Kingdom; ${ }^{5} \mathrm{AbbVie}$ Inc., Rheumatology, North Chicago, United States of America; ${ }^{6}$ University of Glasgow, Rheumatology, Glasgow, United Kingdom

Background: Upadacitinib (UPA) is an oral Janus kinase (JAK) inhibitor engineered to have greater selectivity for JAK1 vs JAK2, JAK3, and tyrosine kinase 2 , and is approved for the treatment of RA. Across 2 double-blind, placebo (PBO)-controlled Phase 3 studies of UPA in patients with RA, after an initial increase through Week 8 , lipid levels remained stable up to Week 24. ${ }^{1,2}$ Previous studies of JAK or IL-6 receptor inhibitors have reported a negative correlation between changes in lipid levels and RA disease activity. ${ }^{3,4}$

Objectives: To determine the relationship between changes in lipid levels and disease activity outcomes in patients with RA treated with UPA.

Methods: Patients with RA and an inadequate response to conventional synthetic/biologic DMARDs (cs/bDMARD-IR) from SELECT-NEXT/SELECT-BEYOND, respectively, were randomized to receive UPA $15 \mathrm{mg}$ once daily (QD), UPA $30 \mathrm{mg}$ QD, or PBO for 12 weeks followed by an extension of up to 5 years; patients randomized to PBO switched to UPA 15 or $30 \mathrm{mg}$ after 12 weeks. Spearman correlations of maximum changes from baseline (BL) through Week 12 in fasting-state lipid levels (low- and high-density lipoprotein cholesterol [LDL-C; $\mathrm{HDL}-\mathrm{C}]$, and total cholesterol [TC]) with clinical disease activity outcomes measured by change from BL in Clinical Disease Activity Index (CDAI), DAS of 28 joints using CRP (DAS28[CRP]), tender/swollen joint count in 28 joints (TJC28/ SJC28), and pain by visual analog scale (VAS) at Weeks 12 and 24, were determined. Spearman correlations of maximum changes from $\mathrm{BL}$ in lipid levels and CRP through Week 12 were also determined.

Results: Available fasting samples from 1,160 pooled patients (UPA $15 \mathrm{mg}$, $\mathrm{n}=386$; UPA $30 \mathrm{mg}, \mathrm{n}=384 ;$ PBO, $\mathrm{n}=390$ ) were included. Modest, but statistically significant, negative correlations were observed between maximum changes from $\mathrm{BL}$ in TC through Week 12 and change from BL in CDAl, DAS28(CRP), SJC28, and pain (VAS) at Week 12 with UPA 15 or $30 \mathrm{mg}$ (Figure 1); similar trends were observed at Week 24. Significant correlations between changes in LDL-C and HDL-C and disease activity outcomes were also observed, but were not consistent across UPA doses and time points. No significant correlations were noted between changes in lipid levels and disease activity outcomes in the PBO group. Statistically significant weak negative relationships were observed between maximum changes from $B L$ in lipid levels and CRP levels through Week 12 with UPA $15 \mathrm{mg}$ (HDL-C and TC) or UPA $30 \mathrm{mg}$ (LDL-C and TC) (Table 1).

Conclusion: In this large pooled data set of patients receiving UPA, increases in lipid levels showed modest, but statistically significant, correlations with improvement in clinical disease activity outcomes in patients with cs/bDMARD-IR RA. These results add to evidence suggesting a relationship between systemic inflammation and lipid metabolism in patients with RA, which is modifiable with effective interventions, and reinforce the importance of monitoring for hyperlipidemia in these patients.

REFERENCES:

[1] Burmester GR, et al. Lancet 2018;391:2503-12.

[2] Genovese MC, et al. Lancet 2018;391:2513-24.
[3] Kremer JM, et al. Arthritis Rheumatol 2017;69:943-52.

[4] Cacciapaglia F, et al. Mediators Inflamm 2018;2018:2453265.

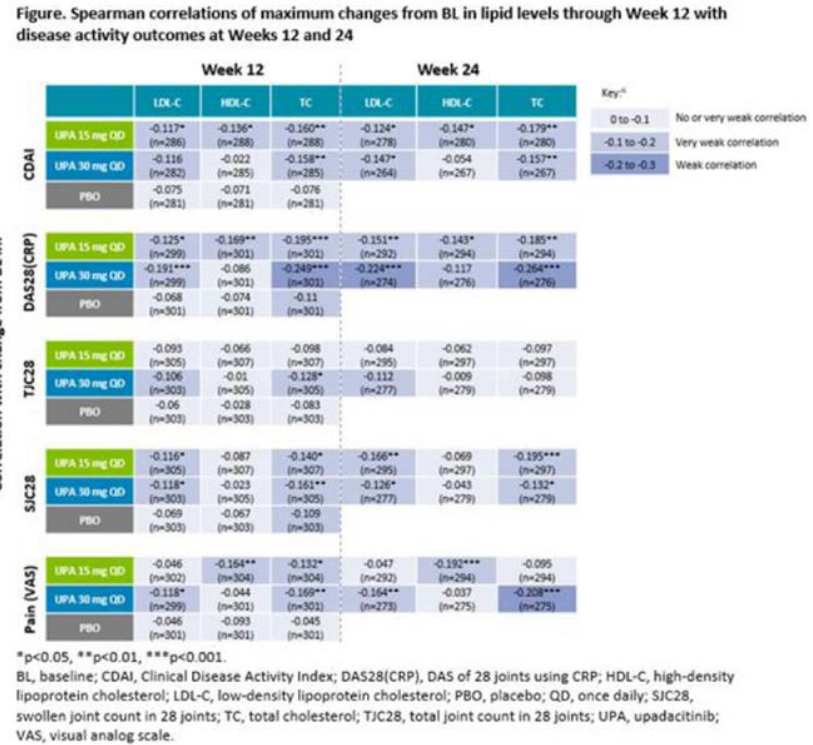

Table 1. Spearman correlation of maximum changes from BL in lipid levels through Week 12 with maximum change from BL in CRP through Week 12

\begin{tabular}{lccc}
\hline & UPA $15 \mathrm{mg}$ QD & UPA 30 mg QD & PBO \\
\hline LDL-C & $-0.099(n=303)$ & $-0.174^{\star *}(n=302)$ & $-0.053(n=303)$ \\
HDL-C & $-0.184^{\star \star}(n=305)$ & $-0.087(n=304)$ & $-0.024(n=303)$ \\
TC & $-0.189^{\star * *}(n=305)$ & $-0.236^{\star \star *}(n=304)$ & $-0.056(n=303)$ \\
\hline
\end{tabular}

${ }^{\star *} \mathrm{p}<0.01,{ }^{\star \star \star} \mathrm{p}<0.001$

HDL-C, high-density lipoprotein cholesterol; LDL-C, low-density lipoproteincholesterol; PBO, placebo; QD, once daily; TC, total cholesterol; UPA, upadacitinib

Acknowledgements: AbbVie funded this study and participated in the study design, research, analysis, data collection, interpretation of data, reviewing, and approval of the publication. All authors had access to relevant data and participated in the drafting, review, and approval of this publication. No honoraria or payments were made for authorship. Medical writing assistance was provided by Frances Smith, PhD, of 2 the Nth, which was funded by AbbVie.

Disclosure of Interests: Christina Charles-Schoeman Consultant of: AbbVie, Gilead, Pfizer, and Regeneron-Sanofi., Grant/research support from: AbbVie, Bristol-Myers Squibb, and Pfizer, Jon T Giles Consultant of: AbbVie, Bristol-Myers Squibb, Eli Lilly, and Gilead, Grant/research support from: Pfizer, Nancy Lane Speakers bureau: Amgen and Mallinckrodt, Consultant of: Amgen, Mallinckrodt, Pfizer, and Roche, Ernest Choy Speakers bureau: AbbVie, Amgen, AstraZeneca, Bio-Cancer, Biogen, Bristol-Myers Squibb Boehringer Ingelheim, Celgene, Chugai Pharma, Eli Lilly, Ferring Pharmaceuticals, GlaxoSmithKline, Hospira, Janssen, Merck Sharp \& Dohme, Napp Novimmune, Novartis, ObsEva, Pfizer, Regeneron, Roche, R-Pharm, Sanofi, SynAct Pharma, Synovate, Tonix, and UCB, Grant/research support from: AbbVie, Amgen, AstraZeneca, Bio-Cancer, Biogen, Bristol-Myers Squibb Boehringer Ingelheim, Celgene, Chugai Pharma, Eli Lilly, Ferring Pharmaceuticals, GlaxoSmithKline, Hospira, Janssen, Merck Sharp \& Dohme, Napp Novimmune, Novartis, ObsEva, Pfizer, Regeneron, Roche, R-Pharm, Sanofi SynAct Pharma, Synovate, Tonix, and UCB, Heidi Camp Shareholder of: AbbVie, Employee of: AbbVie, Yanna Song Shareholder of: AbbVie, Employee of: AbbVie, Samuel Anyanwu Shareholder of: AbbVie, Employee of: AbbVie Iain Mclnnes Consultant of: AbbVie, Celgene, Janssen, Novartis, and UCB Grant/research support from: Celgene, Janssen, Novartis, Pfizer Inc., Roche, and UCB

DOI: 10.1136/annrheumdis-2021-eular.606

\section{POS0657 GEOGRAPHIC VARIATION OF SAFETY IN THE FILGOTINIB RHEUMATOID ARTHRITIS PROGRAM}

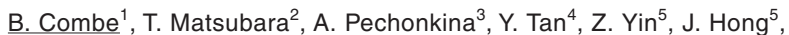
R. Besuyen ${ }^{6}$, A. Gomez-Centeno ${ }^{7}$, M. H. Buch ${ }^{8} .{ }^{1}$ University of Montpellier, Department of Rheumatology, Montpellier, France; ${ }^{2}$ Matsubara Mayflower Hospital, Department of Orthopaedic Surgery, Kato, Japan; ${ }^{3}$ Gilead 
Sciences, Inc., Inflammation and Respiratory Therapeutic Area, Foster City, United States of America; ${ }^{4}$ Gilead Sciences, Inc., Inflammation Therapeutic Area, Foster City, United States of America; ${ }^{5}$ Gilead Sciences, Inc., Biostatistics, Foster City, United States of America; ${ }^{6}$ Galapagos BV, Clinical Development, Leiden, Netherlands; ${ }^{7}$ Hospital Universitari Parc Taulí, Department of Rheumatology, Barcelona, Spain; ${ }^{8}$ University of Manchester, Division of Musculoskeletal \& Dermatological Sciences, Manchester, United Kingdom

Background: The Janus kinase-1 preferential inhibitor filgotinib (FIL) improved signs and symptoms of rheumatoid arthritis (RA) in the FIL clinical program. $^{1-3}$

Objectives: To assess FIL safety across regions.

Methods: This was an analysis of patients (pts) meeting 2010 ACR/EULAR RA criteria in pooled phase (P)2 DARWIN 1-2 (D1-2), P3 FINCH 1-3 (F13), and long-term extension studies (DARWIN 3, FINCH 4). Data were analyzed by region: North America, South and Central America, Western Europe, Eastern Europe, Asia, South East (SE) Asia, and Other. Week (W)12 placebo (PBO)-controlled analysis included data from pts receiving once-daily FIL $100 \mathrm{mg}$ (FIL100), FIL $200 \mathrm{mg}$ (FIL200), or PBO for $\leq 12 \mathrm{~W}$ (D1-2, F1-2); long-term as-treated data included pts from all 7 studies receiving FIL100 or FIL200; data after rerandomization were included and contributed to treatment received. Data presented as exposure-adjusted incidence rates (EAIRs)/100 patient-years of exposure (PYE) of treatment-emergent (TE) adverse events (TEAEs).

Results: Table 1 shows EAIRs of TEAEs in PBO-controlled analysis. EAIRs/100 PYE of all TEAEs in Western Europe, Asia, and Other were higher than in remaining regions and for PBO vs FIL arms; EAIRs for FIL200/FIL100 in North America and SE Asia were higher vs PBO. EAIRs/100 PYE of TE serious AEs were higher in SE Asia for FIL100 and for FIL200/FIL100 in Other, with high PBO EAIRs in Western Europe. EAIRs/100 PYE of TEAEs leading to study discontinuation were higher in FIL arms vs PBO in Western Europe and Other (FIL200); in Asia and SE Asia, EAIRs were higher for PBO vs FIL200/ FIL100.

Table 1. EAIR of TEAEs (placebo-controlled)

\begin{tabular}{|c|c|c|c|c|c|c|c|}
\hline & $\begin{array}{c}\text { North } \\
\text { America } \\
\mathrm{N}=481\end{array}$ & $\begin{array}{c}\text { South and } \\
\text { Central } \\
\text { America } \\
\mathrm{N}=350\end{array}$ & $\begin{array}{l}\text { Western } \\
\text { Europe } \\
\mathrm{N}=141\end{array}$ & $\begin{array}{l}\text { Eastern } \\
\text { Europe } \\
\mathrm{N}=933\end{array}$ & $\begin{array}{c}\text { Asia } \\
N=236\end{array}$ & $\begin{array}{c}\text { South } \\
\text { East Asia } \\
\mathrm{N}=135\end{array}$ & $\begin{array}{l}\text { Other } \\
N=70\end{array}$ \\
\hline \multicolumn{8}{|l|}{ TEAE } \\
\hline & $\begin{array}{r}216.9 \\
(162.5 \\
289.5)\end{array}$ & $\begin{array}{l}205.6 \\
(155.1 \\
272.6)\end{array}$ & $\begin{array}{l}285.0 \\
(188.6 \\
430.8)\end{array}$ & $\begin{array}{l}150.3 \\
(119.3 \\
189.4)\end{array}$ & $\begin{array}{r}248.9 \\
(180.6, \\
343.1)\end{array}$ & $\begin{array}{c}165.1 \\
(104.0, \\
262.1)\end{array}$ & $\begin{array}{r}298.4 \\
(150.3, \\
592.5)\end{array}$ \\
\hline FIL100 & $\begin{array}{r}182 \\
(136 \\
242\end{array}$ & $\begin{array}{c}159.2(117.3, \\
216.1)\end{array}$ & $\begin{array}{c}285.7(183.7 \\
444.3)\end{array}$ & & 3, & $\begin{array}{l}153.7 \\
(94.2 \\
251.0)\end{array}$ & $\begin{array}{l}263.5 \\
(113.9, \\
609.2)\end{array}$ \\
\hline $\mathrm{PBO}^{\mathrm{C}}$ & $\begin{array}{r}174 \\
(130 \\
233\end{array}$ & $\begin{array}{r}162.1 \\
(118.8 \\
221.2)\end{array}$ & $\begin{array}{c}314.9(200.7 \\
493.9)\end{array}$ & 6 & $\begin{array}{l}259.0 \\
(188.0, \\
356.8)\end{array}$ & $\begin{array}{c}81.6(40.8, \\
163.3)\end{array}$ & $\begin{array}{r}306.0 \\
(142.8, \\
655.7)\end{array}$ \\
\hline \multicolumn{8}{|c|}{$T E$ serious $A E$} \\
\hline FIL200 ${ }^{\mathrm{a}}$ & $\begin{array}{c}14.3(6.0 \\
34.4)\end{array}$ & $\begin{array}{c}11.4(3.7 \\
35.5)\end{array}$ & $\begin{array}{c}8.3(1.2 \\
59.0)\end{array}$ & $\begin{array}{c}12.2(5.2 \\
28.7)\end{array}$ & $\begin{array}{c}5.5(0.8 \\
38.9)\end{array}$ & $\begin{array}{c}0.0(0.0 \\
\infty)\end{array}$ & $\begin{array}{l}49.6 \\
(10.2 \\
144.9)\end{array}$ \\
\hline FIL10 & $\begin{array}{c}10.6(4.0 \\
28.3)\end{array}$ & $\begin{array}{c}7.2(1.8 \\
28.7)\end{array}$ & $\begin{array}{c}19.9(5.0 \\
79.7)\end{array}$ & $\begin{array}{c}15.1(6.8 \\
33.7)\end{array}$ & $\begin{array}{c}16.2(5.2 \\
50.2)\end{array}$ & $\begin{array}{c}28.8(9.3 \\
89.4)\end{array}$ & $\begin{array}{c}20.5 \\
(0.5, \\
114.0)\end{array}$ \\
\hline $\mathrm{PBO}^{\mathrm{C}}$ & $\begin{array}{c}16.1(7.2 \\
35.9)\end{array}$ & $\begin{array}{c}7.5(1.9 \\
30.0)\end{array}$ & $\begin{array}{c}29.6(9.5 \\
91.7)\end{array}$ & $\begin{array}{c}4.6(1.3 \\
15.8)\end{array}$ & $\begin{array}{c}11.4(2.8 \\
45.5)\end{array}$ & $\begin{array}{c}10.2(1.4 \\
72.4)\end{array}$ & $\begin{array}{c}0.0(0.0, \\
69.2)\end{array}$ \\
\hline \multicolumn{8}{|c|}{ TEAE leading to discontinuation } \\
\hline FIL200 ${ }^{\mathrm{a}}$ & $\begin{array}{c}8.6(2.8 \\
26.6)\end{array}$ & $\begin{array}{c}3.8(0.1 \\
21.2)\end{array}$ & $\begin{array}{c}16.6(4.2 \\
66.5)\end{array}$ & $\begin{array}{c}12.9(5.5 \\
30.5)\end{array}$ & $\begin{array}{c}0.0(0.0 \\
20.2)\end{array}$ & $\begin{array}{c}9.2(1.3 \\
65.1)\end{array}$ & $\begin{array}{l}16.5 \\
(0.4 \\
92.1)\end{array}$ \\
\hline FIL100 ${ }^{b}$ & $\begin{array}{c}10.6(4.0 \\
28.3)\end{array}$ & $\begin{array}{c}7.2(0.9 \\
26.0)\end{array}$ & $\begin{array}{c}19.9(5.0 \\
79.7)\end{array}$ & $\begin{array}{c}1.9(0.2 \\
13.8)\end{array}$ & $\begin{array}{c}5.4(0.1 \\
30.1)\end{array}$ & $\begin{array}{c}9.6(1.4 \\
68.2)\end{array}$ & $\begin{array}{c}0.0(0.0, \\
75.5)\end{array}$ \\
\hline $\mathrm{PBO}^{\mathrm{C}}$ & $\begin{array}{c}5.4(1.3 \\
21.5)\end{array}$ & $\begin{array}{c}0.0(0.0 \\
13.8)\end{array}$ & $\begin{array}{c}9.9(1.4 \\
70.0)\end{array}$ & $\begin{array}{c}12.9(5.4 \\
30.7)\end{array}$ & $\begin{array}{c}17.1(3.5 \\
49.9)\end{array}$ & $\begin{array}{c}20.4(5.1, \\
81.6)\end{array}$ & $\begin{array}{c}0.0(0.0 \\
69.2)\end{array}$ \\
\hline
\end{tabular}

Data presented as EAIR $(95 \% \mathrm{Cl}) / 100$ patient-years

${ }^{a} \mathrm{~N}=777,179.8$ PYE ${ }^{\mathrm{b}} \mathrm{N}=788,181.6$ PYE ${ }^{\mathrm{N}} \mathrm{N}=781,178.4 \mathrm{PYE}$

A subject may contribute to more than one treatment group if they received more than one treatment of interest.

EAIR and corresponding $95 \% \mathrm{Cl}$ were estimated using Poisson regression model by treatment, including study and treatment with an offset of natural log of exposure time, except when 0 events occurred; Poisson model was not adjusted by study.

$\mathrm{AE}$, adverse event; $\mathrm{Cl}$, confidence interval; EAIR, exposure-adjusted incidence rate; FIL, filgotinib; PBO, placebo; PYE, patient-years of exposure; TE, treatment-emergent Figure shows serious infections (SI), venous thromboembolism (VTE) and herpes zoster (HZ) EAIRs.

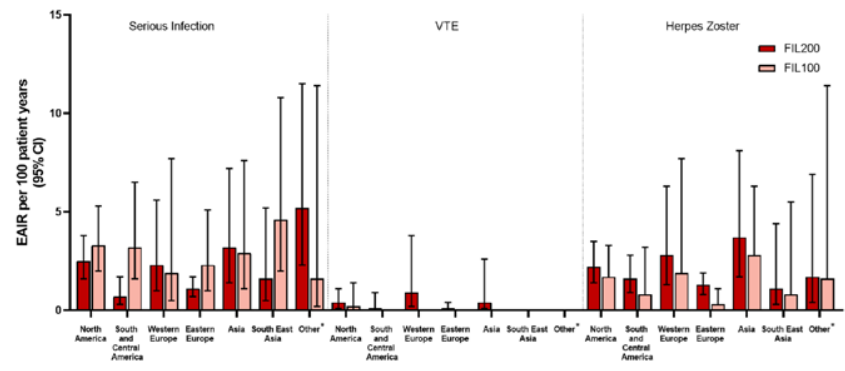

EAIRs for SI were highest in Other for FIL200 and SE Asia for FIL100. While VTE EAIRs were low, pts in 5/7 regions had VTE. HZ EAIRs were highest in Asia. Conclusion: Although EAIR of TEAEs varied between regions, no consistent trend was reflected in any particular region.

\section{REFERENCES:}

[1] Genovese et al. JAMA. 2019;322:315-25.

[2] Westhovens et al. Ann Rheum Dis. 2021; online first.

[3] Combe et al. Ann Rheum Dis. 2021; online first.

Disclosure of Interests: Bernard Combe Speakers bureau: BMS; Eli Lilly \& Co.; Gilead Sciences, Inc.; MSD; Pfizer; Roche-Chugai; and UCB, Consultant of: AbbVie; Eli Lilly \& Co.; Gilead Sciences, Inc.; Janssen; Pfizer; Roche-Chugai; and Sanofi, Grant/research support from: Novartis, Pfizer, and Roche-Chugai, Tsukasa Matsubara Speakers bureau: Pfizer Japan, Nichi-lko, Astellas, Meiji Seika, Bristol-Myers Squibb, AbbVie GK, Janssen, Chugai, Eisai, AYUMI, Alena Pechonkina Shareholder of: Gilead Sciences, Inc., Employee of: Gilead Sciences, Inc., YingMeei Tan Shareholder of: Gilead Sciences, Inc., Employee of: Gilead Sciences, Inc., Zhaoyu Yin Shareholder of: Gilead Sciences, Inc., Employee of: Gilead Sciences, Inc., Jaehyung Hong Shareholder of: Gilead Sciences, Inc., Employee of: Gilead Sciences, Inc., Robin Besuyen Shareholder of: Galapagos, BV, Employee of: Galapagos, BV, Antonio Gomez-Centeno Speakers bureau: AbbVie, Bristol-Myers Squibb, Eli Lilly \& Co., Gebro, Janssen, Menarini, Merck Sharp \& Dohme, Pfizer, Roche, Rubio, Sanofi, and UC, Consultant of: AbbVie, Biogen, Bristol-Myers Squibb, Celgene, Eli Lilly \& Co., Gebro, Gilead Sciences, Inc., Hospira, Merck Sharp \& Dohme, Pfizer, Roche, Rubio Sandoz, Sanofi, Grant/research support from: Boehringer Ingelheim, Celltrion, Eli Lilly \& Co., Galapagos NV, Gilead Sciences, Inc., Novartis, Pfizer, Roche, Sanofi, UCB, YL Biologics, Maya H Buch Speakers bureau: AbbVie; Eli Lilly and Company; Gilead Sciences, Inc.; Merck-Serono; Pfizer; Roche; Sandoz; Sanofi; and UCB, Consultant of: AbbVie; Eli Lilly and Company; Gilead Sciences, Inc.; Merck-Serono; Pfizer; Roche; Sandoz; Sanofi; and UCB, Grant/research support from: AbbVie; Eli Lilly and Company; Gilead Sciences, Inc.; Merck-Serono; Pfizer; Roche; Sandoz; Sanofi; and UCB

DOI: 10.1136/annrheumdis-2021-eular.643

\section{POS0658 GEOGRAPHIC VARIATION OF EFFICACY IN THE FILGOTINIB RHEUMATOID ARTHRITIS PROGRAM}

M. H. Buch ${ }^{1}$, T. Matsubara ${ }^{2}$, B. Combe ${ }^{3}$, A. Pechonkina ${ }^{4}$, Y. Tan ${ }^{5}$, Z. Yin ${ }^{6}$, J. Hong ${ }^{6}$, R. Besuyen ${ }^{7}$, A. Gomez-Centeno ${ }^{8} .{ }^{1}$ University of Manchester, Division of Musculoskeletal \& Dermatological Sciences, Manchester, United Kingdom; ${ }^{2}$ Matsubara Mayflower Hospital, Department of Orthopaedic Surgery, Kato, Japan; ${ }^{3}$ University of Montpellier, Department of Rheumatology, Montpellier, France; ${ }^{4}$ Gilead Sciences, Inc., Inflammation and Respiratory Therapeutic Area, Foster City, United States of America; ${ }^{5}$ Gilead Sciences, Inc., Inflammation Therapeutic Area, Foster City, United States of America; ${ }^{6}$ Gilead Sciences, Inc., Biostatistics, Foster City, United States of America; ${ }^{7}$ Galapagos BV, Clinical Development, Leiden, Netherlands; ${ }^{8}$ Hospital Universitari Parc Taulí, Department of Rheumatology, Barcelona, Spain

Background: The Janus kinase-1 preferential inhibitor filgotinib (FIL) improved signs and symptoms of rheumatoid arthritis (RA) across the FIL clinical program. $^{1-3}$

Objectives: To assess FIL efficacy across geographic regions.

Methods: Pooled data from patients (pts) meeting 2010 ACR/EULAR RA criteria randomised to once-daily FIL $200 \mathrm{mg}$ (FIL200), FIL100 mg (FIL100), or placebo (PBO) with background conventional synthetic disease-modifying antirheumatic drugs in DARWIN 1 (P2; up to week [W]12) and FINCH 1-2 (P3; up to W24) studies were evaluated. Data were analysed by region: North America, South and Central America, Western Europe, Eastern Europe, Asia, South East (SE) Asia and Other. W12 American College of Rheumatology 20\% improvement (ACR20) and W24 Disease Activity Score in 28 joints (C-reactive protein) (DAS28[CRP]) $<2.6$ and $\leq 3.2$ response rates were analysed by a logistic regression model Change from baseline (CFB) in Health Assessment Questionnaire-Disability 